\title{
The effect of the maternal vitamin D level on the risk of spontaneous pregnancy loss in the first trimester
}

\author{
Sharmin Ferdous ${ }^{1 *}$, Farhat Hussain ${ }^{2}$, Samira Hayee ${ }^{3}$, Nahreen Akhtar ${ }^{1}$, \\ Suraiya Khanam ${ }^{4}$, Khadiza Begum ${ }^{5}$, Adeba Sultana ${ }^{5}$
}

\begin{abstract}
${ }^{1}$ Department of Feto Maternal Medicine, ${ }^{4}$ Department of Gyanecological Oncology, Bangabandhu Sheikh Mujib Medical University, Dhaka, Bangladesh

${ }^{2}$ Department of Obstetrics and Gynaecology, SSMC and Mitford Hospital, Dhaka, Bangladesh

${ }^{3}$ Department of Neurology, National Institute of Neuroscience and Hospital (NINS), Dhaka, Bangladesh

${ }^{5}$ Junior Consultant (Obstetrics and Gyanecology), OSD, Director General of Health Services, University, Dhaka, Bangladesh
\end{abstract}

Received: 02 April 2021

Accepted: 03 May 2021

\section{*Correspondence:}

Dr. Sharmin Ferdous,

E-mail: sferdous74@gmail.com

Copyright: (C) the author(s), publisher and licensee Medip Academy. This is an open-access article distributed under the terms of the Creative Commons Attribution Non-Commercial License, which permits unrestricted non-commercial

\begin{abstract}
Background: Pregnancy loss in the first trimester is one of the most disappointing matters for a mother. But spontaneous pregnancy loss in the first trimester is the most common negative outcome of pregnancy. It's estimated that about $10 \%$ of known pregnancies are lost in the first trimester whereas fewer than $4 \%$ of pregnancies miscarry in the second trimester. Aim of current study was to assess the effect of the maternal vitamin D level on the risk of spontaneous pregnancy loss in the first trimester.

Methods: It was a case-control study conducted in the department of obstetrics and gynecology, Sir Salimullah medical college Mitford hospital, Dhaka, Bangladesh during the period of September 2018 to August 2019. A total of 100 patients were included in this study. Statistical analyses of the results were obtained by using window-based computer software devised with SPSS version 22.0.

Results: In analyzing the association of serum vitamin D status with first-trimester pregnancy state it was observed that more than half $(52.0 \%)$ patients had severe deficiency $(<10 \mathrm{ng} / \mathrm{ml})$ in the case group and $14(28.0 \%)$ patients in the control group. In total $24(48.0 \%)$ patients had deficiency $(10-20 \mathrm{ng} / \mathrm{ml})$ in case and $35(70.0 \%)$ in control group. Only $1(2.0 \%)$ patient had insufficiency $(21-29 \mathrm{ng} / \mathrm{ml})$ in control group. The difference was statistically significant $(\mathrm{p}<0.05)$ between the two groups.

Conclusions: Maternal serum vitamin D deficiency was significantly associated with early spontaneous pregnancy loss in the first trimester.
\end{abstract}

Keywords: First trimester, Miscarriage, Serum vitamin D, Gestational age

\section{INTRODUCTION}

Spontaneous pregnancy loss in the first trimester is the most common negative outcome of pregnancy. It's estimated that about $10 \%$ of known pregnancies are lost in the first trimester whereas fewer than $4 \%$ of pregnancies miscarry in the second trimester. Low vitamin D concentrations in pregnancy are widespread worldwide and the effects of vitamin D deficiency in pregnancy have been associated with some adverse pregnancy outcomes. Low levels of vitamin D are common in pregnant women and have been shown in several epidemiological studies worldwide. Vitamin D deficiency is implicated in immune cell regulation at the feto-maternal interface and is associated with pre- 
eclampsia, gestational diabetes, bacterial vaginosis compromised intrauterine growth. The association between deficient vitamin D status and pregnancy loss is less well defined. A history of failed clinical pregnancies may predispose to increased pregnancy loss, decreased serum vitamin D levels among child-bearing-aged women. There are limited studies done to identify the "association of maternal serum vitamin D deficiency with early spontaneous pregnancy loss in the first trimester" in Bangladesh. It has been estimated that almost one billion people in the world suffer from vitamin D deficiency or insufficiency. ${ }^{1}$ In South Asia, $80 \%$ of the apparently healthy population is vitamin D deficient $(<20 \mathrm{ng} / \mathrm{ml})$ and up to $40 \%$ is severely deficient $(<9 \mathrm{ng} / \mathrm{ml}) .^{2}$ In developing countries, the prevalence of hypovitaminosis $\mathrm{D}$ ranges between $30-90 \%$. In North India, $96 \%$ of neonates, $91 \%$ of healthy school girls, $78 \%$ of healthy hospital staff, and $84 \%$ of pregnant were found to have hypovitaminosis D. ${ }^{2}$ In Bangladesh hypovitaminosis D is common in women regardless of age, lifestyle, and clothing with much higher prevalence in low-income lactating women. ${ }^{3}$ In a normal pregnancy, circulating maternal concentrations or $1,25(\mathrm{OH}) 2 \mathrm{D}$ are elevated from the first trimester, there is a progressive increase during gestation, and by the third trimester $1,25(\mathrm{OH}) 2 \mathrm{D}$ is increased over two-fold compared with a post-partum level on non-pregnant controls. Local production of $1,25(\mathrm{OH}) 2 \mathrm{D}$ may be especially important for the increase in the earlier stages of pregnancy, as 1-alpha hydroxilase activity in the desidual and placenta has been observed to be the highest during the first two trimesters. This local activation of vitamin D suggested to influence implantation, partly through the immunomodulation effects $1,25(\mathrm{OH}) 2 \mathrm{D}$ and partly by the regulation of target genes associated with implantation. Effects on implementation could explain the early rising $1,25(\mathrm{OH}) 2 \mathrm{D}$ levels since the demand to meet the increased calcium requirement for mineralization of the fetal skeleton should only increase requirement later in pregnancy. ${ }^{4}$ Vitamin D3 also plays a major role in controlling cell proliferation and maturation and in modulating an immune response in both innate and adaptive forms. ${ }^{5}$ Vitamin D metabolic pathway involves multiple enzymatic reactions. Vitamin D is metabolized in the liver to the form $25(\mathrm{OH}) \mathrm{D}$, which is used to determine a patient's vitamin D status; $25(\mathrm{OH}) \mathrm{D}$ is metabolized in the kidneys by 25 -hydroxyvitamin $\mathrm{D}-1$ alpha-hydroxylase (CYP27B1) to its active form, 1,25$(\mathrm{OH}) 2 \mathrm{D} .^{6}$ The increased synthesis of $1,25(\mathrm{OH}) 2 \mathrm{D}$ is linked to higher CYP27B1 activity in the maternal kidneys, placental trophoblasts, and deciduas. ${ }^{7}$ To date, little is known regarding the determinants of the levels of CYP27B1 in serum, nor a possible association between the level of the enzymes in early pregnancy loss has been explored. A lot of epidemiological published literature refers to the global occurrence of vitamin D deficiency and insufficiency. ${ }^{8}$ In a study they recorded the vitamin D deficiency incidence (a serum level of $<20 \mathrm{ng} / \mathrm{ml}$ ) in women during reproductive age to be $31 \%$. Reports from the "National health and nutrition examination surveys" described that the problem is variable between racial and ethnic categories, "with non-Hispanic blacks possessing a higher rate of vitamin D deficiency and" insufficiency when compared to white ethnic groups. ${ }^{9}$ These results were supported "by Forrest and Stuhldreher, who registered" that blacks had the highest incidence of Vitamin D insufficiency $(82.1 \%)$ and then followed by Hispanics (69.2\%). ${ }^{10}$ In spite of its global prevalence, wide geographical screening for vitamin insufficiency has not been adopted because of the expensive serum assays. For that reason, screening has been carried out only for groups at great risk for vitamin D deficiency. ${ }^{11}$ Recently, a great deal of attention has been focused on vitamin status during pregnancy. Evidence about the role of vitamin $\mathrm{D}$ in human reproduction has been proved by a number of researchers. ${ }^{12}$ Globally, vitamin D deficiency is a frequent problem among women at the age of childbearing. ${ }^{13}$

\section{General objectives}

General objective of the study was to assess the effect of the maternal vitamin D level on the risk of spontaneous pregnancy loss in the first trimester.

\section{Specific objectives}

Specific objectives of the study were to collect the sociodemographic information of the participants, to collect information regarding sunlight exposure and the clothing style of the participants, to collect information regarding the dietary habits of the participants and to dig out the association of serum vitamin D status with first-trimester pregnancy.

\section{METHODS}

Presented study was a case-control study conducted in the department of obstetrics and gynecology, Sir Salimullah medical college Mitford hospital, Dhaka, Bangladesh during the period September 2018 to August 2019. A total of 100 patients were included in this study. Among them, 50 pregnant women having early spontaneous pregnancy loss in the first trimester (documented by ultrasonography as missed or incomplete abortion) was considered as a case (group I). Age, gestational age, and BMI matched another 50 women in their early live pregnancy (documented by ultrasonography) was served as control (group II). A purposive sampling method was used in this study. According to the inclusion criteria of this study women having regular menstrual cycles, 21-35 years of age, BMI within the range of $18.5-29.9 \mathrm{~kg} / \mathrm{m}^{2}$ were included. Besides these, cases were pregnant women with early spontaneous pregnancy loss. Gestational age and BMI matched pregnant women with early live pregnancy comprised the control subjects. On the other hand, according to the exclusion criteria of this study pregnant women using vitamin $\mathrm{D}$ or hormone at least 3 months prior to enrolment or with multiple pregnancies, autoimmune disorders, chromosomal 
abnormalities, thyroid dysfunction, diabetes mellitus, renal dysfunction, and malignancy were excluded. Age of the patient, occupation, education, locality or area of residence, socio-economic condition, and personal behavior were considered as demographic variables of this study. Gestational age and number of pregnancy loss were the obstetric variables. Anthropometric variables were height $(\mathrm{M})$, weight $(\mathrm{Kg})$ and BMI $\left(\mathrm{Kg} / \mathrm{m}^{2}\right)$. Serum vitamin D level $25(\mathrm{OH}) \mathrm{D}(\mathrm{ng} / \mathrm{ml})$ was considered as a biochemical variable. The gestational age was calculated from the last menstruation period (LMP) and ultrasonography. All the subjects attending and outpatient department of obstetrics and gynecology, Sir Salimullah medical college Mitford hospital, Dhaka, Bangladesh during the study period and who fulfilled the inclusion criteria were enrolled in the study. A physical examination of all the participants was done. The demographic and obstetrics information was collected in a pre-structured datasheet. The body weight of the participants was measured barefooted. The average weight $(0.5 \mathrm{~kg})$ of the clothes was later deducted from the dignified weight. The measurement of weight was done after the bladder has been emptied and before a meal. The heights of the subjects were measured barefooted in the standing position with meter scales. Body mass index was determined by measuring weight $(\mathrm{kg})$ divided by height square (meter). The blood sample was collected for measurement of $25(\mathrm{OH}) \mathrm{D}$ levels. Vitamin $\mathrm{D}$, in the form of $25(\mathrm{OH}) \mathrm{D}$ estimation was carried out by a chemiluminescent microparticle immunoassay using the ARCHITECT in the laboratory of the biochemistry department of BSMMU. Vitamin D levels were defined as 'severe deficiency: $<10 \mathrm{ng} / \mathrm{ml}$ ', 'deficiency: 10-20 $\mathrm{ng} / \mathrm{ml}$ ', 'insufficiency: 21-29 $\mathrm{ng} / \mathrm{ml}$ ', and 'sufficiency: $\geq 30 \mathrm{ng} / \mathrm{ml}$. Statistical analyses of the results were obtained by using window-based computer software devised with SPSS version 22.0.

\section{RESULTS}

In current study in both the case and control groups, the highest numbers of participants were from the 21-25 years' age group which was $80 \%$ in group I and $68 \%$ in group II. The mean age was $22.88 \pm 1.88$ years in group I and $23.96 \pm 3.56$ years in group II. Two third $(66.0 \%)$ of patients had primary education in group I and $29(58.0 \%)$ in group II. The majority of patients were housewives and belonged to rural areas in both groups. The majority of the patients had normal BMI in both groups. The mean BMI was $22.26 \pm 1.52 \mathrm{~kg} / \mathrm{m} 2$ in group I and $22.35 \pm 1.4$ $\mathrm{kg} / \mathrm{m} 2$ in group II. None of the demographic parameters were statistically significant. It was also observed that all (100.0\%) patients belonged to lower middle income in group I and group II. The difference was statistically not significant $(p>0.05)$ between the two groups. Besides these, it was found that the majority $(86.0 \%)$ of patients in group I and $41(82.0 \%)$ patients in group II had sunlight exposure for $<1 / 2$ hour.

Table 1: Socio-demographic status of participants $(n=100)$.

\begin{tabular}{|c|c|c|c|c|c|}
\hline \multirow{3}{*}{ Characteristics } & \multirow{2}{*}{\multicolumn{2}{|c|}{$\begin{array}{l}\text { Group I } \\
(\mathbf{N}=\mathbf{5 0})\end{array}$}} & \multicolumn{2}{|l|}{ Group II } & \multirow{3}{*}{$P$ valuc } \\
\hline & & & $(\mathbf{N}=\mathbf{5 0})$ & & \\
\hline & Frequency & $\%$ & Frequency & $\%$ & \\
\hline \multicolumn{6}{|l|}{ Age (years) } \\
\hline $21-25$ & 40 & 80.0 & 34 & 68.0 & \multirow{3}{*}{0.080} \\
\hline $26-30$ & 9 & 18.0 & 13 & 26.0 & \\
\hline $31-35$ & 1 & 2.0 & 3 & 6.0 & \\
\hline Mean \pm SD & \multicolumn{2}{|l|}{$22.88 \pm 1.88$} & \multicolumn{2}{|l|}{$23.96 \pm 3.56$} & \multirow{2}{*}{0.061} \\
\hline Range (min-max) & $20-33$ & & $20-35$ & & \\
\hline \multicolumn{6}{|l|}{ Education } \\
\hline No education & 9 & 18.0 & 11 & 22.0 & \multirow{3}{*}{0.712} \\
\hline Primary & 33 & 66.0 & 29 & 58.0 & \\
\hline Secondary & 8 & 16.0 & 10 & 20.0 & \\
\hline \multicolumn{6}{|l|}{ Occupation } \\
\hline Housewife & 31 & 62.0 & 21 & 42.0 & \multirow{4}{*}{0.086} \\
\hline Service & 6 & 12.0 & 4 & 8.0 & \\
\hline Domestic worker & 13 & 26.0 & 24 & 48.0 & \\
\hline Daily labor & 0 & 0.0 & 1 & 2.0 & \\
\hline \multicolumn{6}{|l|}{ Area of residence } \\
\hline Urban & 10 & 20.0 & 12 & 24.0 & \multirow{2}{*}{0.629} \\
\hline Rural & 40 & 80.0 & 38 & 76.0 & \\
\hline \multicolumn{6}{|c|}{ Family income status (per month) } \\
\hline Lower & 0 & 0.0 & 0.0 & 0.0 & \multirow{3}{*}{-} \\
\hline Lower-middle & 50 & 100.0 & 50.0 & 100.0 & \\
\hline Upper-middle & 0 & 0.0 & 0.0 & 0.0 & \\
\hline
\end{tabular}


The majority $(90.0 \%)$ of the patients wore a veil in group I and $44(88.0 \%)$ in group II. The difference was statistically not significant $(p>0.05)$ between the two groups. In current study $12(24.0 \%)$ patients used to consume milk 4 times a week in group I and $16(32.0 \%)$ in group II. Eight $(16.0 \%)$ patients had egg consumption per day in a group I and $6(12.0 \%)$ in group II.

Table 2: Sunlight exposure and clothing style of participants $(n=100)$.

\begin{tabular}{|c|c|c|c|c|c|}
\hline \multirow{3}{*}{ Parameters } & \multirow{2}{*}{\multicolumn{2}{|c|}{$\begin{array}{l}\text { Group I } \\
(\mathbf{N}=\mathbf{5 0})\end{array}$}} & \multirow{2}{*}{\multicolumn{2}{|c|}{$\begin{array}{l}\text { Group II } \\
(\mathbf{N}=\mathbf{5 0})\end{array}$}} & \multirow{3}{*}{ P value } \\
\hline & & & & & \\
\hline & Freq. & $\%$ & Freq. & $\%$ & \\
\hline \multicolumn{6}{|c|}{ Sunlight exposure in hours/day } \\
\hline$<1 / 2$ & 43 & 86.0 & 41 & 82.0 & \multirow{3}{*}{0.585} \\
\hline $1 / 2-1$ & 7 & 14.0 & 9 & 18.0 & \\
\hline$>1$ & 0 & 0.0 & 0 & 0.0 & \\
\hline \multicolumn{6}{|c|}{ Clothing style } \\
\hline With veil & 45 & 90.0 & 44 & 88.0 & \multirow{2}{*}{0.749} \\
\hline Without veil & 5 & 10.0 & 6 & 12.0 & \\
\hline
\end{tabular}

Table 3: Distribution of dietary habits regarding vitamin D containing food $(n=100)$.

\begin{tabular}{|c|c|c|c|c|c|}
\hline \multirow{3}{*}{$\begin{array}{l}\text { Dietary } \\
\text { habits }\end{array}$} & \multirow{2}{*}{\multicolumn{2}{|c|}{$\begin{array}{l}\text { Group I } \\
(\mathrm{N}=\mathbf{5 0})\end{array}$}} & \multirow{2}{*}{\multicolumn{2}{|c|}{$\begin{array}{l}\text { Group II } \\
(\mathbf{N}=\mathbf{5 0})\end{array}$}} & \multirow{3}{*}{$\mathbf{P}$ value } \\
\hline & & & & & \\
\hline & Freq. & $\%$ & Freq. & $\%$ & \\
\hline \multicolumn{6}{|c|}{ Milk consumption 4 times a week } \\
\hline Yes & 12 & 24.0 & 16 & 32.0 & \multirow{2}{*}{0.373} \\
\hline No & 38 & 76.0 & 34 & 68.0 & \\
\hline \multicolumn{6}{|c|}{ Egg consumption per day } \\
\hline Yes & 8 & 16.0 & 6 & 12.0 & \multirow{2}{*}{0.564} \\
\hline No & 42 & 84.0 & 44 & 88.0 & \\
\hline \multicolumn{6}{|c|}{ Small fish intake per day } \\
\hline Yes & 44 & 88.0 & 46 & 92.0 & \multirow{2}{*}{0.505} \\
\hline No & 6 & 12.0 & 4 & 8.0 & \\
\hline
\end{tabular}

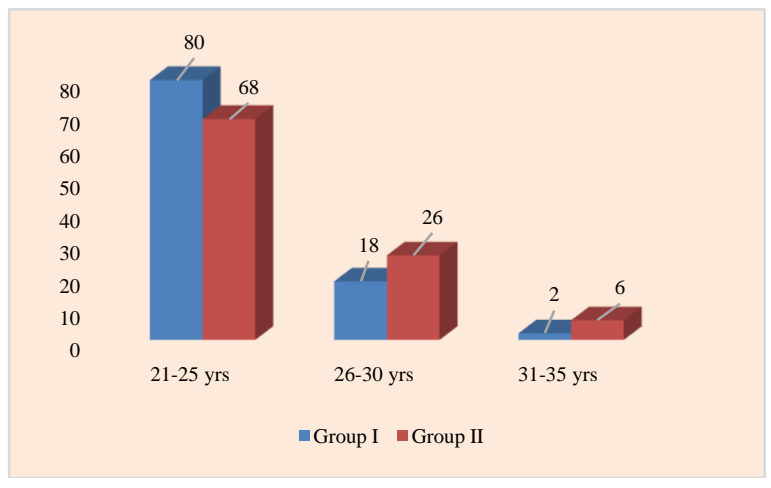

Figure 1: Group wise patient's age distribution.

The majority $(88.0 \%)$ patients had small fish intake per day in group I and $46(92.0 \%)$ in group II. The difference was statistically not significant $(p>0.05)$ between the two groups. It was observed that more than half $(52.0 \%)$ patients had severe deficiency $(<10 \mathrm{ng} / \mathrm{ml})$ in group I and
$14(28.0 \%)$ patients in group II. $24(48.0 \%)$ patients had deficiency $(10-20 \mathrm{ng} / \mathrm{ml})$ in group I and $35(70.0 \%)$ in group II. Only $1(2.0 \%)$ patient had insufficiency (21-29 $\mathrm{ng} / \mathrm{ml}$ ) in group II. None of the patients had sufficient serum vitamin D levels. It was observed that the mean vitamin D level was $9.98 \pm 2.56 \mathrm{ng} / \mathrm{ml}$ in group I and $11.51 \pm 2.96 \mathrm{ng} / \mathrm{ml}$ in group II. The difference was statistically significant $(p<0.05)$ between the two groups. In analyzing the association of serum vitamin D status with first-trimester pregnancy state it was observed that more than half $(52.0 \%)$ patients had severe deficiency $(<10 \mathrm{ng} / \mathrm{ml})$ in the case group and $14(28.0 \%)$ patients in the control group. In total $24(48.0 \%)$ patients had deficiency $(10-20 \mathrm{ng} / \mathrm{ml})$ in case and $35(70.0 \%)$ in control group. Only $1(2.0 \%)$ patient had insufficiency $(21-29 \mathrm{ng} / \mathrm{ml})$ in control group. The difference was statistically significant $(p<0.05)$ between the two groups.

Table 4: Distribution of the study subjects according to vitamin $D$ level in $\mathrm{ng} / \mathrm{ml}(\mathrm{n}=\mathbf{1 0 0})$.

\begin{tabular}{|lllll|}
\hline \multirow{2}{*}{ Vitamin D levels } & \multicolumn{2}{l}{ Group I } & \multicolumn{2}{l|}{ Group II } \\
\cline { 2 - 5 } & $(\mathbf{N = 5 0 )}$ & \multicolumn{2}{l|}{$\mathbf{( N = 5 0 )}$} \\
\hline Severe deficiency $(<\mathbf{1 0})$ & Freq. & \% & Freq. & \% \\
\hline Deficiency (10-20) & 24 & 52.0 & 14 & 28.0 \\
\hline Insufficiency (21-29) & 0 & 0.0 & 1 & 2.0 \\
\hline Sufficiency (30) & 0 & 0.0 & 0 & 0.0 \\
\hline
\end{tabular}

Table 5: Comparison of serum vitamin D level between the patients group $(n=100)$.

\begin{tabular}{|llll|}
$\begin{array}{llll}\text { Vitamin D } \\
\text { level }(\mathbf{n g} / \mathbf{m l})\end{array}$ & $\begin{array}{l}\text { Group I } \\
\mathbf{( N = 5 0 )}\end{array}$ & $\begin{array}{l}\text { Group II } \\
\mathbf{( N = 5 0 )}\end{array}$ & P value \\
\cline { 1 - 3 } Mean \pm SD & $9.98 \pm 2.56$ & $11.51 \pm 2.96$ & \multirow{2}{*}{$<0.01$} \\
\cline { 1 - 2 } & $6.7-14.5$ & $8.8-21.7$ & \\
\hline
\end{tabular}

Table 6: Association of serum vitamin D status with first trimester pregnancy state $(n=100)$.

\begin{tabular}{|c|c|c|c|c|c|}
\hline \multirow{3}{*}{$\begin{array}{l}\text { Vitamin D } \\
\text { levels }\end{array}$} & \multirow{2}{*}{\multicolumn{2}{|c|}{$\begin{array}{l}\text { Group I } \\
(\mathbf{N}=\mathbf{5 0})\end{array}$}} & \multirow{2}{*}{\multicolumn{2}{|c|}{$\begin{array}{l}\text { Group II } \\
(\mathbf{N}=\mathbf{5 0})\end{array}$}} & \multirow{2}{*}{ P value } \\
\hline & & & & & \\
\hline & Freq. & $\%$ & Freq. & $\%$ & \multirow{5}{*}{$<0.05$} \\
\hline $\begin{array}{l}\text { Severe } \\
\text { deficiency }\end{array}$ & 26 & 52 & 14 & 28 & \\
\hline Deficiency & 24 & 48 & 35 & 70 & \\
\hline Insufficiency & 0 & 0 & 1 & 2 & \\
\hline Sufficiency & 0 & 0 & 0 & 0 & \\
\hline
\end{tabular}

\section{DISCUSSION}

In current present study, it was observed that the majority of the patients had normal BMI in both groups. The mean BMI was $22.26 \pm 1.52 \mathrm{~kg} / \mathrm{m} 2$ in group I and $22.35 \pm 1.4$ $\mathrm{kg} / \mathrm{m} 2$ in group II. The difference was statistically not significant $(\mathrm{p}>0.05)$ between the two groups. In a study by Ghaedi et al it was found that $66.7 \%$ of those with SPL and $58.3 \%$ of the women with RPL had normal BMI ${ }^{15}$ In another study, Andersen et al observed that the 
maternal BMI was $23.26 \mathrm{~kg} / \mathrm{m} 221.01-27 \mathrm{~kg} / \mathrm{m}^{2}$ in group I and $23.38 \mathrm{~kg} / \mathrm{m}^{2}$ varied from $21.26-26.18 \mathrm{~kg} / \mathrm{m}^{2}$ in group II, which is similar to the present study. ${ }^{16-18}$ In current study, it was observed that $52.0 \%$ patients had severe deficiency $(<10 \mathrm{ng} / \mathrm{ml})$ and $48.0 \%$ in deficiency (10-20 ng/ml). The mean vitamin D level was $9.98 \pm 2.56$ $\mathrm{ng} / \mathrm{ml}$ varied from $6.7-14.5 \mathrm{ng} / \mathrm{ml}$. Shareif et al found the mean vitamin D level was $11.5 \pm 3.1 \mathrm{ng} / \mathrm{ml}$ in women with a history of pregnancy loss, which is comparable with the present study. ${ }^{17}$

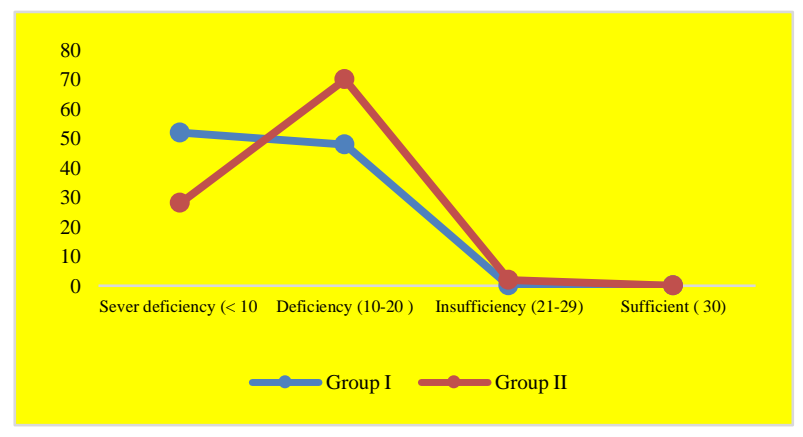

Figure 2: Group wise patient's vitamin D status.

Kuhr et al observed $25.6 \%$ of patients had a deficiency and $74.4 \%$ had insufficiency. ${ }^{18}$ Kota et al observed that $41.4 \%$ had women with pregnancy loss were vitamin D deficient. ${ }^{19}$ In current study, it was observed that the mean vitamin D level was $9.98 \pm 2.56 \mathrm{ng} / \mathrm{ml}$ in group I and $11.01 \pm 2.96 \mathrm{ng} / \mathrm{ml}$ in group II. The difference was statistically significant $(\mathrm{p}<0.05)$ between the two groups. Similarly, Li et al also found that serum vitamin D level was significantly decreased in pregnancy loss $(42.49 \pm 11.17 \mu \mathrm{g} / \mathrm{l})$ when compared to the control group $(50.57 \pm 3.18 \mathrm{mg} / \mathrm{l})$ suggesting that an altered localized maternal vitamin D state may influence pregnancy outcome. ${ }^{20}$ In current study, it was observed that $52.0 \%$ of patients had severe deficiency $<10 \mathrm{ng} / \mathrm{ml}$ in group I and $28.0 \%$ of patients in group II. $48.0 \%$ of patients had deficiency $10-20 \mathrm{ng} / \mathrm{ml}$ in group I and $70.0 \%$ in group II. Only $2.0 \%$ of patients had insufficiency $21-29 \mathrm{ng} / \mathrm{ml}$ in group II. The difference was statistically significant $(p<0.05)$ between the two groups. Adequate vitamin D concentrations were essential during pregnancy. Vitamin $\mathrm{D}$ deficiency in the mother could be vertically transmitted to the fetus. The risk of pregnancy loss in pregnant women with a low concentration of vitamin $\mathrm{D}$ is 1.71 with 95\% CI: 1.2-2.4. It means that vitamin D deficiency was associated with PL in the first-trimester of pregnancy. Kuhr et al observed $25.6 \%$ of patients had a deficiency and $74.4 \%$ had insufficiency in women with recurrent pregnancy loss. ${ }^{18}$ In another study by Kota et al observed that $41.4 \%$ had women with pregnancy loss were vitamin D deficient. On the other hand, Moller et al studies did not find an association between vitamin D deficiency and the clinical outcome of miscarriage in the first-trimester pregnancy. ${ }^{19,21}$ This discrepancy may be explained not only by methodological differences but also by differences in this study population relative to other published studies, including the difference in maternal age and gestational age of specimen collection.

\section{Limitations}

Limitations of the current study were; it was a singlecentered short lengthen study with a small sample size. So, the findings of this study might not reflect the precise scenario of the whole country. Samples were taken by the purposive method in which questions of personal biases might arise. Confounding variables for vitamin D deficiency could not be excluded.

\section{CONCLUSION}

Serum vitamin D deficiency is evident in almost all the study participants but it is significantly lower in pregnant women with early spontaneous pregnancy loss in the first trimester than in control. For getting more reliable information we would like to recommend conducting more studies in several places with larger sample size. We can consider serum vitamin $\mathrm{D}$ as a screening test in the pre-conceptional period and intervention programs for raising vitamin D levels in those women can be carried out in order to prevent vitamin D deficiency linked to pregnancy loss in the first trimester.

\section{Funding: No funding sources}

Conflict of interest: None declared

Ethical approval: The study was approved by the Institutional Ethics Committee

\section{REFERENCES}

1. Holick MF. Vitamin D deficiency. N Engl J Med. 2007;357(3):266-81.

2. Malhotra N, Wahl DL \& Bonjour JP 2009. 'Vitamin D status in Asian. Global vitamin D status and determinants of hypovitaminosis D. Osteoporos Int. 2009;20(11):1807-20.

3. Islam MZ, Lamberg-Allardt C, Kärkkäinen M, Outila T, Salamatullah Q, Shamim AA. Vitamin D deficiency: a concern in premenopausal Bangladeshi women of two socio-economic groups in rural and urban region. Eur J Clin Nutr. 2002;56(1):51-6.

4. Hyppönen E. Vitamin D for the prevention of preeclampsia? A hypothesis. Nutr Rev. 2005;63(7): 225-32.

5. Lagishetty V, Liu NQ, Hewison M. Vitamin D metabolism and innate immunity. Mol Cell Endocrinol. 2011;347(1-2):97-105.

6. Christakos S, Dhawan P, Benn B, Porta A, Hediger M, Oh GT, et al. Vitamin D: molecular mechanism of action. Annals New York Acad Sci. 2007; 1116(1):340-8.

7. Diaz L, Sánchez I, Avila E, Halhali A, Vilchis F, Larrea F. Identification of a 25-hydroxyvitamin D3 1á-hydroxylase gene transcription product in cultures of human syncytiotrophoblast cells. J Clin Endocrinol Metab. 2000;85(7):2543-9. 
8. Mitchell DM, Henao MP, Finkelstein JS, BurnettBowie SA. Prevalence and predictors of vitamin D deficiency in healthy adults. Endocr Pract. 2012; 18(6):914-23.

9. Looker AC, Johnson CL, Lacher DA, Pfeiffer CM, Schleicher RL, Sempos CT. Vitamin D status: United states, 2001-2006. NCHS data brief. 2011; 59(59):1-8.

10. Forrest KY, Stuhldreher WL. Prevalence and correlates of vitamin D deficiency in US adults. Nutr Res. 2011;31(1):48-54.

11. Kennel KA, Drake MT, Hurley DL. Vitamin D deficiency in adults: when to test and how to treat. Mayo Clin Proc. 2010;85(8):752-8.

12. Lerchbaum E, Rabe T. Vitamin D and female fertility. Curr Opin Obstet Gynecol. 2014;26(3):145-50.

13. Woo J, Lam CW, Leung J, Lau WY, Lau E, Ling $\mathrm{X}$, et al, Very high rates of vitamin $\mathrm{D}$ insufficiency in women of child-bearing age living in Beijing and Hong Kong. Br J Nutr. 2008;99(60):1330-4.

14. Flood-Nichols SK, Tinnemore D, Huang RR, Napolitano PG, Ippolito DL. Vitamin D deficiency in early pregnancy. PLoS One. 2015;10(4): e0123763.

15. Ghaedi N, Forouhari S, Zolghadri J, Sayadi M, Nematollahi A, Khademi K. Vitamin D deficiency and recurrent pregnancy loss in Iranian women. Curr Opin Obstet Gynecol. 2016;29(4):157-9.

16. Andersen LB, Jørgensen JS, Jensen TK, Dalgård C, Barington T, Nielsen J, Beck-Nielsen SS, Husby S, Abrahamsen B, Lamont RF, Christesen HT. Vitamin $\mathrm{D}$ insufficiency is associated with increased risk of first-trimester miscarriage in the Odense Child Cohort. Am J Clin Nutr. 2015;102(3):633-8.

17. Shareif PDM, Mahmood DSK, Al-Abassy DNH. The association of serum vitamin $\mathrm{d}$ and calcium levels with early recurrent spontaneous pregnancy loss. J Med Sci Clin Res. 2008;6(11):272-7.

18. Kuhr DL, Sjaarda LA, Alkhalaf Z, Omosigho UR, Connell MT, Silver RM, et al. Vitamin D is associated with bioavailability of androgens in eumenorrheic women with prior pregnancy loss. Am J Obstet Gynecol. 2018;218(6):608.e1-6.

19. Kota AK, Kwon G, Choi W, Mabry JM, Tuteja A. Hygro-responsive membranes for effective oilwater separation. Nature Comm. 2012;3:1025.

20. Li N, Wu HM, Hang F, Zhang YS, Li MJ. Women with recurrent spontaneous abortion have decreased $25(\mathrm{OH})$ vitamin $\mathrm{D}$ and VDR at the fetal-maternal interface. Braz J Med Biol Res. 2017;50(11):e6527.

21. Møller UK, Streym S, Heickendorff L, Mosekilde L, Rejnmark L. Effects of 25OHD concentrations on chances of pregnancy and pregnancy outcomes: a cohort study in healthy Danish women. Eur J Clin Nutr. 2012;66(7):862-8.

Cite this article as: Ferdous S, Hussain F, Hayee S, Akhtar N, Khanam S, Begum K, et al. The effect of the maternal vitamin D level on the risk of spontaneous pregnancy loss in the first trimester. Int J Reprod Contracept Obstet Gynecol 2021;10:221520. 